\title{
Coping with Global Warming: Strategy and Action
}

\author{
Liang Daingcai ${ }^{1}$ * ${\text { Zhang } \mathrm{Bo}^{2} \text { Wang Yang }}^{3}$ \\ ${ }^{1,2}$ Yunnan university of finance and economics \\ (dingcai2008@126.com,1925362488qq.com) \\ ${ }^{3}$ Yunnan university of graduate student (546686046qq.com)
}

\begin{abstract}
Global warming is already beyond doubt problem, climate change has become a thre at to the sustainable development of human society. All countries in the world should take measures to deal with this problem. Global warming is more and more serious. As a developing country, faced with such serious situation, the Chinese government showed a responsible power image for the countries all over the world. This article first discusses the status quo of the problem of global warming, and then discusses China to deal with the problem of global warming has taken measures.
\end{abstract}

Keywords: Global Warming; Strategy; Action.

\section{Introduction}

Since the west industrial revolution, the population of the world in the sharp has increased dramatically. At the same time, the human break a large number of cultivated land and the forest resources, and combusted chemical raw materials in the mass production and economic activities. But, the human release a large amount of greenhouse gases. These gases cause atmospheric composition change and lead to the global climate more and more warmer. According to the American scientists (1979) estimated, if the Carbon dioxide gas doubled, the average global temperature will increase 1.5 to 4.5 .And further research points out. It is thus clear that, if human beings constantly release carbon dioxide, the temperature of the earth will continue to rise.

So, the global warming has what effect to China? In fact, the global warming to China has very big effect. First of all, the global warming will affect the climate of our country. Our country vegetation zone will move north, the coral reefs, mangroves, tropical rain forest, northern grassland wetland, natural grassland ecological' s adaptability will be threatened. And glaciers and lakes will also greatly reduced. Secondly, the climate warming makes farmland increase plant diseases and insect pests, and affect agricultural harves. Finally, the global warming has some negative influence, such as drought, floods, sandstorm, forest fire, etc.

Since the 1978s, the problem of global warming has caused attention by the scientific commuity governments and the international community. The Chinese government has attached great importance to this problem. In 1992, china set up "the state council leading group for coordination of climate change", the institution included the ministry of foreign affairs, the state science and technology commission, the state planning commission, the ministry of water resource, china meteorological administration, chinese academy of sciences, etc. In June 2007, the Chinese government promulgated the planning about climate warming. In October 2008, the Chinese government announced the white paper about climate change. At the same time, the Chinese government implemented the policy of energy conservation and emissions reduction. In addition, the Chinese government has started to strengthen international communication and cooperation.

\section{The Overview about the Problem of Global Warming}

\subsection{The Situation of Global Warming}

The climate is the main part of the natural world, and the human society survival and development cannot leave the climate. The climate of any changes will be to the natural world and human society caused great influence. In recent years, Global climate going through a field to warming as the main characteristics of the significant change , but also because of this, the problem of global warming to get the attention of the countries all over the world. In order to solve this problem, The United Nations intergovernmental panel on climate change (IPCC) respectively have been done four evaluation in 1990, 1995, 2001 and 2007. After, the four evaluation shows: at present the average global temperature has increased.

Visible, the global climate system warming 
is obvious, is beyond question.

\subsection{Strategies and Action in Different Countries}

The problem of global warming has produced great influence to the ecological system and the social economy about the countries all over the world. Global warming has become a major issues of common concern of mankind. At the same time, all countries are taking various measures to cope with global warming.

Some countries through the implementation of two measures to reduce global warming progress and amplitude, and this two measures is "To adapt to the effects of climate change and reduce greenhouse gas emissions”.

At the same time, the coping measures are divided into two kinds of national and internation by some countries. Among them, the national policy measures include emissions, carbon or energy tax, allowance, voluntary agreement, do not trade license, etc, and international policies and measures including international emissions trading (IET), Joint performance (JI), International voluntary agreement, etc.

In addition, some countries trying to reduce $\mathrm{CO} 2$ emission reduction efforts to reduce global temperature.

Although the national action to some extent alleviate global warming speed, but only rely on some of the power of the state can't solve the problem. To solve this problem, the countries all over the world to protect the common interests of mankind from the start, and carry out a wide range of global cooperation. In order to take effective measures to control the global climate warming in the global scope, The United Nations founded the intergovernmental negotiations committee (INC) in December 1990,this agency dedicated to discuss global warming's international convention. Through the efforts of all countries, the problem of global warming has been some control. Of course, In the face of global warming, human beings are still facing many difficulties.

\section{China Strategies Coping with Global Warming}

As is known to all, global warming is tangible, Climate change has affected the sustainable development of the human society. To promote the sustainable development of society, and to solve the problem of global warming, the Chinese government has put forward the new Strategys and action as follows:

\subsection{To Enhance the Efficiency of Energy Utilization}

At present, the Chinese government attaches great importance to change the mode of economic growth and the adjustment of economic structure. For example, the Chinese government through promoting cleaner production to reduce industrial pollution, and adjusting the first industry and the proportion of the second industry to promote the development of the tertiary industry.

\subsection{To Develop Low Carbon Energy and \\ Renewable Energy}

The Chinese government takes measures to increase policy and fund investment, for example, to drum water power, nuclear power, petroleum, natural gas and coalbed methane (CBM) development and utilization, be like again, to support utilize the Biomass energy, solar energy, geothermal energy, wind energy and so on the new renewable energy in the countryside, remote areas and conditions suitable for areas.

\subsection{To Strengthen Ecological Construction and Protection}

The Chinese government increases the forest area, and actively implementing natural forest protection, restoration of farmland to forest and pasture, grassland construction and management, the nature reserve construction, ecological construction and protection policy. Meanwhile, China's urban landscaping work also has got very fast development, the 2005 China city built up area green coverage reached 1.06 million hectares, green coverage of $33 \%$, urban per capita public green space of 7.9 square meters, this part of the green space to absorbing atmospheric carbon dioxide also play a role.

\subsection{Carry out Family Planning, and Control Population Growth.}

Since the 1970s, the Chinese government had decided to put the population planning policy as a basic state policy, so as to effectively control the growth of China's population .In addition, the family planning policy to reduce the number of the population, but also reduce the carbon emissions.

\subsection{Restrain Behaviors through Legal and Institutional Means}

The Chinese government realized that it is difficult to implemented about the measure of energy conservation and emission reduction, after all, China's large population. In order to implement the policy of energy conservation and emissions reduction, the Chinese government 
formulates relevant laws, from the system level to restrain the behavior of people.

\subsection{Strenthen Propaganda and Education of \\ Dealing Withclimate Xhanges}

In recent years, the Chinese government has increased the propaganda and education of climate change, and has Carryed out various forms of knowledge about climate change lectures and report. In addition, the Chinese government ofter hosts some trainings about the climate change in the national scope.

\subsection{Reference to the Advanced Experience from Other Countries}

The Global warming has been paid attention by the countries all over the world. Some countries have very rich experience to reduce carbon emissions, so the Chinese government decided to reference and learn these experiences. For example, in November 2009, the Chinese government and the United States signed San Francisco plan, thus to introduce advanced experience from the United States.

\subsection{To Seek International Cooperation and \\ Communication}

As is known to all, global warming is an international problem, Solving the problem of global warming need to cooperate and exchange of experience. In the framework of the United Nations, carry out the United Nations framework convention on climate change, and to discuss the issue of global warming by holding international meeting. The Chinese government believes that solving the problem of global warming core measures is to stick to the "The United Nations framework convention on climate change convention", "The Kyoto protocol" and "Bali roadmap".

\section{Conclusions}

Without a doubt, global warming has effect on the survival and development of human society. At the same time, the Global warming is more and more serious. Faced with such serious situation, the Chinese government showed a responsible power image for the countries all over the world. China implements various effective measures to respond to the problem of global warming. China is active participants in the search for global warming measures, So far, China has signed 103 environmental protection agreement with 97 countries. In addition, the Chinese government realized that global warming is not only individual countries, and it is an international problem. Therefore, global warming need to concerted effort from the countries all over the world.

\section{References}

[1] IPCC. Summary for Policymakers of the Synthesis Report of the IPCC Third Assessment Report. Cambridge. UK: Cambridge University Press. 2001.

[2] IPCC. Summary for Policymakers of the Synthesis Report of the IPCC Fourth Assessment Report. Cambridge, UK: Cambridge University Press. 2007.

[3] The national climate change countermeasures coordination team office, China in the 21st century agenda management center. Global climate change: human beings are facing with the challenge, Beijing: the commercial press. 2004.

[4] Xu Zairong. Global environmental problems and the international response. China's environmental press. 2007.

[5] Gong Ying, Gbal warming and China's response, jilin university institute of northeast Asia, 2010.

[6] Zhang Kunmin, Wen Zongguo, China's Point of View and Countermeasures on Global Warming, China Soft Science 7th, 2001.

[7] Qu Zhongqiong, Cheng Cangchun, Study about Influence and Solution of Global Warming on Human Health, SICHUAN ENVIRONMENT, 2004, 23(5).

[8] Ran ShengHong. Global change to our country the influence of fragile area economic development [J]. Journal of resources science, 2001, 23(3): 24-28.

[9] CaiYunLong etc. Global climate change Chinese agricultural vulnerability and countermeasures $[\mathrm{J}]$. Journal of geography, 1996, 51(3): 202-126.

[10] Sun ChengQuan etc. Global climate change, new understanding: IPCC third climate change assessment report overview [J]. Journal of natural, 2002, 24(2): 114-122.

[11] Dai JunHu. The greenhouse effect and global warming introduction to study [J]. World environment, 2001 (4): 18-21.

[12] CengRong, WeiYiMing, FanYing, LiZhiJie, $\mathrm{Xu}$ WeiXuan, the population, resources, the environment, economic coordination's development and analysis [J] system engineering theory and practice 2000 and 1-6.

[13] Consideration on the Current Global Climate Change[J]. China's population: Resources and Environment, 2005, 81-82. 